\title{
Are brace prescribers following standards?
}

\author{
Aïssatou Fall*, Marie Beauséjour, Marjolaine Roy-Beaudry, Lise Goulet, Hubert Labelle \\ From 7th International Conference on Conservative Management of Spinal Deformities \\ Montreal, Canada. 20-22 May 2010
}

\section{Introduction}

Even if braces for scoliosis are broadly used in Canada, there is no data on the orthopaedic medical practice to evaluate the circumstances of brace prescription. This study aims at comparing scoliosis brace prescription patterns with generally recognized standards.

\section{Materials and methods}

A cross-sectional study was carried out between March 2006 and March 2007, on all confirmed AIS patients aged 10 to 18 , who were referred to a pediatric scoliosis clinic in a major referral center for a first visit. Agreement between the actual brace prescription patterns and the criteria for immediate prescription was analyzed using a kappa coefficient. Standard recommendations supported by the Quebec Scoliosis Network (QSN) were used, as well as the Scoliosis Research Society (SRS) therapeutic inclusion criteria. In addition, logistic regression models were used to identify variables related to brace prescription.

\section{Results and discussion}

Amongst the 321 AIS patients, immediate brace treatment was recommended in 70 cases, for about $50 \%$ of concordance with the defined criteria (Table 1). Variables describing the patients' maturity (age, Risser, onset of menses) and curve magnitude (Cobb angle and rib hump) were associated with brace prescription. In multivariate analyses, the prescription patterns differed mostly by physicians.

\section{Conclusion}

Despite the professional consensus on immediate bracing, under and over prescription of brace were documented in this study. Better understanding of these patterns would require documentation of motives associated with prescription at the individual level. An

Sainte-Justine Hospital, Montreal, Canada

Full list of author information is available at the end of the article investigation of the physicians' beliefs, attitudes and intentions appears essential to achieve better ways of following therapeutic norms for brace prescription.

Published: 10 September 2010

doi:10.1186/1748-7161-5-S1-040

Cite this article as: Fall et al:: Are brace prescribers following standards? Scoliosis 2010 5(Suppl 1):040.
Submit your next manuscript to BioMed Central and take full advantage of:

- Convenient online submission

- Thorough peer review

- No space constraints or color figure charges

- Immediate publication on acceptance

- Inclusion in PubMed, CAS, Scopus and Google Scholar

- Research which is freely available for redistribution
Ciomed Central 
Table 1 Agreement between actual brace prescription and defined criteria (QSN and SRS)

\begin{tabular}{|c|c|c|c|c|c|}
\hline & \multicolumn{2}{|c|}{ QSN immediate prescription criteria } & \multicolumn{3}{|c|}{ SRS therapeutic inclusion criteria } \\
\hline & \multicolumn{2}{|c|}{$\begin{array}{c}\text { Risser }[0-3] \\
\text { Cobb }\left[30^{\circ}-45^{\circ}\right]\end{array}$} & \multicolumn{2}{|c|}{$\begin{array}{c}\text { Risser }[0-2] \\
\text { Cobb }\left[25^{\circ}-40^{\circ}\right]\end{array}$} & \multirow[b]{2}{*}{ Tota } \\
\hline & yes & no & yes & no & \\
\hline \multicolumn{6}{|c|}{ Actual brace prescription } \\
\hline yes & 36 & $34^{b}$ & 37 & $33^{b}$ & 70 \\
\hline no & $24^{\mathrm{a}}$ & 227 & $17^{\mathrm{a}}$ & 234 & 251 \\
\hline Total & 60 & 261 & 54 & 267 & 321 \\
\hline Kappa & \multicolumn{2}{|c|}{$k=0.441 ; p<0.001$} & \multicolumn{2}{|c|}{$k=0.502 ; p<0.001$} & \\
\hline
\end{tabular}

${ }^{\mathrm{a}}$ : under-prescription

b : over-prescription 